\title{
The weakness of strong policies and the strength of weak policies: Law, experimentalist governance, and supporting coalitions in European Union health care policy
}

\author{
Scott L. Greer \\ Department of Health Management and Policy, University of Michigan School of Public Health, Ann Arbor, \\ MI, USA
}

\begin{abstract}
The experience of European Union (EU) health care services policy shows the importance of supporting coalitions in any effort to effect policy change and the extent to which the presence or absence of such coalitions can qualify generalizations about policymaking. EU health care services law is substantively liberalizing and procedurally driven by the courts, with little legislative input. But the European Court of Justice (ECJ) has been much better at establishing an EU competency in law than in causing policy development in the EU or member states. Literature on courts helps to explain why: courts are most effective when they enjoy supporting coalitions and the ECJ does not have a significant supporting coalition for its liberalizing health care services policy. Based on interview data, this article argues that the hard law of health care services deregulation and the newer forms of health care governance, such as the Open Method of Coordination and the networks on rare diseases, depend on supporting coalitions in member states that are willing to litigate, lobby, budget, decide cases, and otherwise implement EU law and policy. Given the resistance that the Court has met in health care sectors, its overarching deregulatory approach might produce smaller effects than expected, and forms of experimentalist governance that are easy to deride might turn out to have supporting coalitions that make them unexpectedly effective.
\end{abstract}

Keywords: European Union, experimentalist governance, courts, OMC, health care, health policy.

\section{Introduction}

There is a fundamental constitutional asymmetry in the European Union (EU) (Scharpf 2002). Put simply, EU institutions are more effective and powerful at liberalizing, marketmaking activities than they are at developing positive legislation (Streeck \& Schmitter 1991; Leibfried \& Pierson 1995; Ferrera 2005).

The substance of EU law is asymmetrical. The treaties that constitute the EU create strong legal grounds for court decisions and legislation to create integrated European

Correspondence: Scott L. Greer, Department of Health Management and Policy, University of Michigan School of Public Health, 1415 Washington Heights, Ann Arbor, MI 48109-2099, USA. Email: slgreer@umich.edu

Accepted for publication 22 February 2011. 
markets. The "four freedoms" - the freedom of movement within the EU of goods, services, capital, and people - are powerful principles in EU law. They justify removing member state policies that interfere with the internal market and the European Court of Justice (ECJ) typically allows only narrow exceptions to them. The EU budget, meanwhile, is small - capped at just over 1\% of the EU's gross domestic product (GDP) - and is a fraction of the kind of money member states spend on welfare.

The procedures of EU policymaking are also asymmetrical. The EU's legislative process is complex and filled with veto points. Passing legislation through such a process is slow and uncertain, while introducing legislation is a right confined to the executive (the European Commission). Neither the directly elected European Parliament nor the Council, where states vote, has the ability to introduce legislation. They can only amend. By contrast, the EU's judicial branch and executive are less rigid. The ECJ can receive cases from courts across the EU and make decisions whose consequences can in most cases be modified by only the slow EU legislative route. The Commission has considerable discretionary and agenda-setting autonomy, including the right to bring enforcement cases against states that do not implement EU law.

In this account, the EU is a powerful engine for liberalization but is not as good at making counteracting laws that harmonize minimum standards, creating compensating welfare programs, or protecting country-specific institutions that enhance welfare but conflict with ECJ rulings. This explains why the EU has been such a success at market making - and why there is no EU welfare state (Kleinman 2002; Moravcsik 2002; Ferrera 2005; Anderson 2009; Newdick 2009). It also explains why there has been such scholarly and practical interest in "experimentalist governance" (Sabel \& Zeitlin 2010) - mechanisms that would create EU-level social policy despite the limitations of the Treaties and the difficulties of the legislative process. Experimentalist governance mechanisms are an effort to introduce concepts that are not in the treaties - such as a commitment to quality, solidaristic, and financially sustainable health care - and mechanisms that will promote those objectives without going through the difficult legislative process.

I argue that the constitutional asymmetry of the EU is overdrawn. The legislative process, executive politics, and ECJ all have built-in biases toward negative integration and market making. But those apparently strong policies are still subject to multiple forms of implementation failure and can lose political momentum if opponents outnumber supporters. On the other hand, apparently weak, voluntary initiatives based on benchmarking, data collection, and networks might be stronger than they first appear. What they lack in the authority of law they might make up in supporters eager to implement them on the ground and further them in EU political debates.

The second section of the article presents this case. It argues that the common denominator of effective policies, established or experimental, is a supporting coalition of litigants who will file cases against non-compliance with EU law, of lobbyists who will press for the necessary legislative and policy changes, of courts that will enforce and refer cases filed under the new jurisprudence, of technical and legal experts who can give specificity to broad goals, of bureaucratic elites who oversee policy drafting and implementation, and of ministers who are willing to legislate and budget for policy change. Without a supporting coalition, there is a short-run likelihood that decisions will have little or no compliance and a medium-run likelihood that the EU institutions, lacking a supporting coalition, will tire of failure and reduce their efforts at policymaking in the policy area. 
The third section reviews the "hard law" that created the EU's new competencies in health care services policy. The ECJ showed its power and autonomy vis-à-vis states and interest groups by extending internal market law to health care services despite the lack of support for such an agenda. The Commission, member states, and Parliament started to develop policy in order to create legal certainty lacking in case by case legal development and corral the developing policy into a legislative arena that they controlled. But participants in the legislative process for health care services have had the general problem of the EU: difficulty finding treaty bases for positive heath care rights and difficulty constructing the coalitions that would pass them. The story told in the section shows both the extent of constitutional asymmetry - in the unbidden creation of a liberalizing EU competency - and the difficulty of legislating less-liberalizing policy. But the history of the political debates and the developing evidence on EU health care services policy impact also show the limited nature of the support coalition behind liberalization and the strong resistance.

The fourth section reviews some of the experimentalist governance. First, it discusses a benchmarking exercise called the Open Method of Coordination (OMC), widely heralded as the most effective EU-level mechanism for raising levels of welfare provision and promoting positive integration. Then it turns to sectoral programs such as the network on rare disease and the networks on communicable disease control. The OMC is a mechanism for considering and possibly changing entire welfare states, and is easy to tar as vague and macroscopic. The rare diseases network and others such as cancer research are mechanisms for considering and possibly changing a tightly defined area of health care services. The comparison of law and experimentalist governance mechanisms highlights the importance of supporting coalitions: the OMC, like the Court, lacks an obvious supporting coalition, but more focused networks can gain such coalition support.

The fifth section, the conclusion, argues that mechanisms of experimentalist governance that develop networks and harmonize standards in very specific areas such as the treatment of rare diseases might be as effective at policy change in their areas as law or possibly the OMC. That is because they, unlike the bulk of EU initiatives under internal market law, can have clear uses for incumbents within health policy communities. And in the longer run, the weaknesses of judicially driven liberalization might emerge. The grand designs of EU law might be stalemated by political and bureaucratic resistance, while the more specific plans of specific networks might find receptive hosts in the EU.

This article relies on two major data sources. These interviews allowed me to interpret data from the second source: a review of 124 interviews conducted since 2004 in Brussels (EU institutions and lobbies) and four member states (France, Germany, Spain, and the UK), supplemented by short re-interviews and observation of EU events in Brussels, Gastein, and London. The interviews included at least two Commission desk officers for each policy area discussed; member state desk officers (at least one each in the health ministry and permanent representation in Brussels); regional government officials involved in implementing EU policy for at least four regional governments each in Germany, Spain, and the UK; and the Brussels lobbies of the principal EU health care lobbies as well as regional government and member state health care lobbies' Brussels offices (see also Greer 2009). In many cases I was able to interview two people in the same job as these are mostly high-turnover positions. These interviews allowed me to interpret data from a review of the documented history of a variety of policy initiatives, drawing on the work of EU legal scholars and policy debates. 


\section{Supporting coalitions}

Students of courts and policy have often found that the law is not as powerful as it might seem. The ultimate impact of law or judicial decisions, like guidelines or norms, depends on the extent to which they enjoy a supporting coalition whose members, especially any politicians, lower courts, officials, and interest groups, are willing to support them in legislating, policymaking, budgeting, implementation, lobbying, litigating, and legal judgments.

\subsection{Courts and law}

Courts in general have limited ability to impose their preferences. They must wait for cases to come to them, even in an abstract review setting, and so they depend on litigants who are willing to bring the cases (and lower courts to refer them). They depend on others to implement their decisions. They neither manage nor budget. Judges are not policy experts and implementing legally well-founded decisions can be a challenge in practice. As a result, courts must interact with politicians, bureaucrats, and litigants if their decisions are to change policy and its implementation: they must find a supporting coalition (Rosenberg 1991; Canon \& Johnson 1999). The relationship between jurisprudence and policy is complex, but courts in general shy away from making decisions that will not be implemented and often retreat if they face too much political resistance (Epp 2008).

Studies suggest that the specific case of the ECJ fits with these general expectations. They suggest that its decisions, if they are to have an impact on policy, need to have some kind of supporting coalition. Member states' initial response to adverse ECJ rulings is usually "contained compliance:" they comply with the most minimal interpretation of the decision (Conant 2002), and many countries ignore decisions made with regard to other jurisdictions. Only if there is a stream of cases challenging them, and building up jurisprudence outside their control, will most states start to both implement seriously and consider EU-level political responses such as legislation or new governance. They might, at the same time, start to seek EU legislation or other instruments that would allow them to reassert at least some of their control over the policy framework (Börzel 2006). The insight that a supporting coalition is necessary to (at a minimum) provide litigants has underpinned an important strand of work on EU legal development and its impact (Alter \& Vargas 2000; Cichowski 2007), while the best explanation of the rise of EU law has focused on its attractiveness to member state lower courts, an important part of the supporting coalition for the ECJ itself (Alter 2001).

Courts are not alone in requiring a supporting coalition in order to effect change. The literature on Europeanization focuses on legislation and makes the same point: change in response to EU policy tends not to happen without supporters promoting the change in the member states (Graziano \& Vink 2007). It is not just a simple concept of "match" or "mismatch" that determines whether member states implement policy to the satisfaction of the Commission and Court; it is also determined by whether there are groups seeking to use the EU policy as an opportunity for policy change (Héritier 2001; Smith 2005).

\subsection{Experimentalist governance}

The need for a supporting coalition is more obvious in experimentalist governance because it amounts to little or nothing without the participation of significant actors. 
Newer forms of governance in the EU, such as the OMC, appeared in response to the EU's difficulty affecting policies, whether because there were no supportive coalitions for EU policies or because the constitutional asymmetry of the EU left it with little or no power to act in important areas (Wincott 2003). We see this in the explicit reasoning of the White Paper on Governance in the $\operatorname{EU}(\operatorname{COM}(2001) 428)$, which formally introduced a number of alternative policymaking partnerships and forums into EU governance, and the conclusions of the 2000 decisions by the Council $^{1}$ that made health care an official part of the EU policy apparatus (de la Porte et al. 2002). We also see this in the "prehistory" of such governance (states comparing plans and performance before such activity was named and formalized as an EU policy instrument), the long-standing ubiquity of networks in EU governance (Sabel \& Zeitlin 2007), and even suggestions in 2010 that European states might peer review each others' draft budgets. The risk is that the relevant organizations will not join experimentalist mechanisms or will pay only lip service to their decisions - that their leaders will agree to shared objectives and then do something else. The reasons they might do something else are numerous: political conflict (Page 2005), broader domestic political priorities, administrative incapacity (Schout et al. 2010), and bureaucratic isolation of the people who attend the international meetings (Greer 2010).

If they work, such forms of experimentalist governance compensate for constitutional asymmetry by extending the EU role and EU-wide coordination into areas outside the core of internal market law and the range of priorities in EU action beyond the four freedoms, and they compensate for the possibility of overreach by integrating much broader parts of government as well as, possibly, civil society. Their weakness is that, even more than the Court, they depend on a supporting coalition: hard law, at least in theory, demands compliance, while newer forms of governance, if they do nothing to elicit a supporting coalition, can be ignored by all but a few ministry bureaucrats.

\section{Hard law and constitutional asymmetry in European Union health care services governance}

The EU's constitutional asymmetry has heretofore allowed the ECJ to wield power over health care in Max Weber's classic definition of power as the "chance of a man or a number of men to realize their own will in a social action even against the resistance of others" (Weber 1946, p. 180). There is essentially no evidence of economic, political, or social supporting coalitions behind the ECJ's move into health care services (Martinsen 2005; Greer 2006; Lamping \& Steffen 2009). As with most social policy, there was minimal demand for integration and member states were reticent about writing it into the treaties as an EU competency. Nevertheless, the ECJ created the EU competency and developed a jurisprudence treating health care as a service. Neither EU legislative politics nor events in most member states, though, show a supporting coalition to implement or further its jurisprudence.

\subsection{Status quo ante: Social security coordination and treaties}

There was not much demand for new patient mobility law because there was an existing regime that incorporated most organized actors in health care. EU patient mobility policy began in 1959 (with Regulation 3, one of the first EU laws) and took its current form with Regulations 1408/71 and 883/2004. Under social security law (which produced the Euro- 
pean health insurance card [EHIC]), citizens of EU member states have a right to emergency treatment abroad, which is reimbursed by their member state. They can only have publicly financed nonemergency health care outside their member state of residence if their home (paying) member state "pre-authorizes" it. Furthermore, much crossborder patient mobility takes place in clearly identifiable border regions such as the Pyrenees, the Alps, and the Benelux (Rosenmöller et al. 2006). In many cases the member states and regional governments involved have treaties and associated agreements. These are pragmatic, tailored to local situations, and could, legally, exist without the EU. Likewise, UK National Health Service (NHS) decisions around 2000-2001 to send patients abroad for care did not draw on specific EU health law; they simply involved contracts between the UK Department of Health and particular French and Belgian providers (four interviews, UK Department of Health, 2004-2009; also Glinos et al. 2010b).

\subsection{Freedom to provide services}

The ECJ took a different approach from 1998 when it made the important Kohll (1998) and Decker (1998) decisions. Substantively, it ruled that EU citizens could be reimbursed by their home countries for health care services purchased in different countries on the grounds that limiting reimbursement to services purchased at home interferes with the freedom of movement of services. These decisions applied the law on the internal market, specifically the freedom to provide services stated at the time in Article 49 of the Treaties, to health care (when the Lisbon Treaty came into effect, Article 49 became Article 56). The shift in legal approach is important because it meant that at least some health care services were subject to at least some EU internal market law. The logic of the two decisions meant that even if eligibility for social security financing remained a matter for member states under social security law, the member states were interfering with the right to provide services if they kept their citizens from using their public social security benefits to purchase health care services in other member states.

The ECJ went on to develop a quite full jurisprudence, one that gradually extended the scope of internal market law in health care from the initial marginal cases (of spectacles and orthodontia in reimbursement systems) to the full range of non-hospital and some hospital care anywhere in the EU. Defining "hospital" and "non-hospital" care has been a considerable challenge for policymakers and lawyers because it seems there is little or no consistency about the meaning of hospitals or what kinds of care take place in them across Europe (interviews, European Health Management Association, London, May 2004; European Commission, Gastein, October 2009). The ECJ and its AuditorsGeneral (who draft opinions) also experimented with a variety of other legal principles that would help it identify discrimination, including the possibility that there was such a thing as an unreasonable waiting time (in the Auditor-General's report for Watts ${ }^{2}$ (2005)) and the possibility that member states should have to use "European" criteria in deciding what to cover (in the ECJ's decision in Geraets-Smits and Peerbooms ${ }^{3}$ (2001)). The ECJ drew back: it opted not to decide on the legitimacy of or criteria for appropriate waiting lists in Watts (2005). It also refrained from repeating its demand for "European" standards since Geraets-Smits and Peerbooms (2001).

By 2006, the ECJ had made it clear that internal market law applies to health care subject to balancing demands for public health and the financial stability of health care systems (Hervey \& Vanhercke 2010). Such balancing raises at least two questions. To what extent would a range of EU internal market laws covering issues such as competition, 
state aids to enterprise, and public procurement turn out to apply to health? And, what would balancing mean: What kinds of organizations in a given country would be able to claim what kinds of exemptions from what aspects of internal market law?

These were big questions to have open. Potentially, huge areas of internal market law could apply, opening up much of health care to private sector competition, undermining a variety of risk-pooling arrangements and imposing transaction costs. Health ministry interviewees in Britain, France, and Germany all spoke (in 2006, 2009, and 2007 interviews) of the alarming results of the in-house impact analyses they conducted. Academic and policy analyses identified interpretations that would be costly and might require major structural reforms (Busse et al. 2002; McKee et al. 2002a,b). These questions led member states to ask the Commission for a legislative proposal. Legislation would start to answer those questions by fixing health care as a kind of service with a particular insertion into internal market law, and the legislative process that would give member states and elected politicians the input that they did not have into the Court's decisions.

The Commission's first legislative response was to incorporate health care services into its 2004 proposal for a Services Directive intended to liberalize a range of services across Europe. This proposal, which codified and in many ways went beyond the most liberal of the Court's rulings, produced a backlash in general (Crespy 2010) and in health care (Greer 2009; Jarman \& Greer 2010). When it passed the European Parliament, amendments included removal of health care from its remit.

\subsection{Freedom of movement of people}

After the failure to include health care in the Services Directive, the EU was left with a badly stitched legal "patchwork" (Hervey \& Vanhercke 2010). Social security coordination, treaties, and cross-border agreements all remained intact. Patient mobility based on the freedom to provide services remained entrenched in ECJ decisions even if it had failed in legislation. With little additional debate the Parliament and Council called for the Commission to bring forth a proposal for legislation that would be specific to the health care sector and balance markets with regulation and integration with subsidiarity

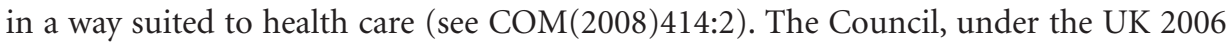
Presidency, spelled out its preferences: universality, equity, solidarity, and the autonomy of member states. ${ }^{4}$ These values were meant as a rebuke to the Commission and a reminder of the values member states felt were left out of the Court rulings and Commission proposals to date (interviews, UK and German governments, October 2006).

The problem for policymakers was to find a legal basis for a policy that would fit with the existing decisions without making health care a service and that would allow more presumptively popular patient focus without relying on the EU's very weak formal competencies over health care services. The Commission prepared a draft that included extensive discussions of patient safety, redress, and information as well as other mechanisms that would make it more patient-friendly. This is the proposed Directive on cross-border patient mobility $(\operatorname{COM}(2008) 414)$. The "recitals," the important preliminary declarations that are guidance as to legislative intent, emphasized free movement of people rather than commerce in health care services. It would allow member states to require pre-authorization for "hospital" care, defined as expensive and high-technology care. A patient from a poor country who sought treatment under the Directive in a rich country would have to pay all travel and care costs out of pocket and then be reimbursed at the much lower tariff of his or her home state. ${ }^{5}$ 
The Directive passed the European Parliament in 2009 but not the Council. Many member states in the Council opposed the whole concept of EU health care services law. Interviewees, from, for example, the health ministries and permanent representations of the UK, Germany, and then-President Sweden, argued to me in late 2009 that it was necessary to pass EU legislation precisely in order to control the Court and prevent it further assimilating health care services to the freedom to provider services. The Directive finally passed the Council in January 2010.

\subsection{Reactions to EU health care law and supporting coalitions}

There are two notable aspects of the story. The Court exercised a quite pure form of power, extending EU competencies and incorporating health care into the internal market despite a general lack of demand for such law and only the (literally) weakest of allies - sick individuals. The member states and Commission found it difficult to respond. This story is compatible with the constitutional asymmetry of the EU.

But the effects on EU health systems were rather less dramatic than the legal principles might have predicted. Research is starting to emerge on the effects of the health decisions on different member states (Martinsen \& Vrangbaek 2008; Martinsen \& Blomqvist 2009; Obermaier 2009; Baeten et al. 2010; Glinos et al. 2010a,b; Wismar et al. 2010; Greer \& Rauscher 2011a,b). Broadly, this research finds variable but often minimal responses by health policymakers and health systems, consonant with Conant's "contained compliance" thesis (2002). There are only glimpses of what might be, or become, a supporting coalition in member states for the developing regulatory framework of EU health care services law - the supporting coalition that the literature suggests further policy change requires. Conceptually, the coalition is made up of groups who would benefit from a stronger EU competency. Support for stronger EU health care policies can be for one of two reasons.

First, it could be out of a desire to engage in cross-border arbitrage - to actually compete for patients across borders. Cross-border health care is a small market: many estimates put it at around 1-2\% (Carrera \& Lunt 2010), with one interviewee (an executive for a major health insurer, interviewed in June 2010) putting the most optimistic estimate for the market at $4 \%$ of European patients. Most such patients are concentrated in border regions or a few particularly attractive areas for retirement or second homes (Spanish coasts, London). Cost, the single biggest driver of international patient mobility, is less of a problem in the EU's universal coverage systems (Jarman et al. 2010; Laugesen \& Vargas-Bustamente 2010).

Second, a supporting coalition could be interested in exploiting the regulatory destabilization inherent in developing EU law. EU law regulates states' policy decisions, potentially making policy tools that depend on territorial closure unusable. This means that EU law offers another means of effecting domestic policy change. For example, rationing by waiting becomes a less useful policy tool insofar as EU law permits patients to go abroad for care and then seek reimbursement. Purely legal analyses suggest that such risks to closure exist and that EU legal principles could be used to remove important regulations (Hatzopoulos 2010). There have also been cases in which incumbent private firms used EU public procurement and state aid law to challenge policies (van de Gronden 2009), including two salient health care cases in health care. In the Asklepios (2008) case, a private German hospital chain objected to what it saw as subsidies to public sector competitors, while in the BUPA (2008) case an insurer objected to an Irish government 
decision to make it subsidize a public insurance pool. In both cases, however, the decision of the EU courts amounted to an affirmation of the autonomy of health care systems. ${ }^{6}$ In a characteristic EU judicial solution, the Court ruled that the member states must have clear and transparent rules for deciding such issues, switching responsibility to states and their procedures.

The cases since 2006 have been brought by individual patients trying to improve their social rights through EU law. For example, in the recent Elchinov (2010) case, a Bulgarian man argued that Bulgaria had granted him a right to the "best available treatment," and the best available treatment was available not in Bulgaria, but in Germany (where, of course, it cost far more) (Sokol forthcoming). The list of cases is essentially a list of names, each name a patient who sought mobility as a way to get better health care, and the stories rarely show organized interests behind them. The effect of this kind of case has been that the ECJ is presented with opportunities to decide what rules health services must use in determining eligibility for treatment. This might be a blow for expanded social rights, but from the perspective of, for example, financially constrained Bulgarian health managers, it is a serious problem.

\section{New governance}

It is not surprising that the development of hard, destabilizing law on health care services sparked the development of alternative experimentalist governance frameworks. The Court's rulings and logic left it relatively exposed, with much more opposition among incumbents than support. The European Commission, meanwhile, is very well suited to developing and presenting policy alternatives. Not only is it an entrepreneurial organization with a long record of developing ideas for EU initiatives of all sorts (Shore 2007; Cram 2009), it is also a fragmented organization with many departments (DirectoratesGeneral [DGs]) of different orientations. These compete for influence in different policy fields, and so the effect of the ECJ rulings was to spur a variety of DGs to propose different health care policies (Greer 2008). DG Internal Market's proposal was the Services Directive, and DG Health and Consumer Protection (a.k.a. DG Sanco) is responsible for the Directive on cross-border patient mobility. But parts of the Commission also suggest experimentalist governance frameworks that might win supporting coalitions.

Two experimentalist frameworks have particularly strong institutional support within the Commission and might satisfy that holder of destabilization rights as well as incumbent health care services players: the OMC (run by DG Employment, Social Affairs and Equal Opportunities, a.k.a. DG EMPL) and a range of special groups run by DG Sanco. They are ringed by other committees, groups, and platforms working in EU health policy, most of which either are high-level committees with no specific powers or role in policy change or are focused on public health and not the focus of this article (Jarman forthcoming).

In each case they arose and gained momentum in response to the threat that health care services would be simply assimilated to internal market law. While their creation was usually due to a variety of motivations - Commission entrepreneurialism, interest group or professional interest, member state pressure - they also are ways to "recapture" health care services from the Court and internal market law. If nothing else, they allow health services policymakers to talk about issues such as quality and cost of health care, rather than internal market laws. 


\subsection{The Open Method of Coordination}

The OMC is a peer-review process for a wide range of social policies, including health policy. The basic format is the same in each policy area and is the subject of a more than adequate amount of academic literature (Wincott 2003; Zeitlin 2005; Hatzopoulos 2007 has an extensive bibliography). Sophisticated analysts of the EU's "destructuring... deterritorializing" impact on welfare states put much hope in the OMC as a mechanism to reinforce Europe's social obligations (Ferrera 2005).

Member states agree on a basic set of objectives and indicators of desirable outcomes. They then produce national action plans on what they are planning to do and reports on their achievements. The Commission (DG EMPL) and the other member state representatives discuss and feed the member state's data into a Joint Report commenting on its progress. In many cases the member state's report and the Joint Report are quite similar.

There is a running debate about the effects of the OMC that is not just academic:

Since I was specifically asked to address it, I will take a minute to talk about the OMC. Is this being recorded? Yes? All of it? Let me phrase this carefully then. I have been told ... I have heard ... what is that? Did somebody say it doesn't work? (DG Sanco official, 2 October 2009)

Obvious bureaucratic rivalry means we should expect that a DG Sanco official would denigrate DG EMPL's signature health policy tool, especially in 2008-2009 when DG EMPL was openly leaking information detrimental to the patient mobility Directive in the hopes that it would fail and health care services would be folded back into social security law. Such "downright infighting," as one member state official called it in an interview, is common in the Commission. Likewise, it should not be too surprising that a little-known exercise conducted at the official level has failed to change policies in many member states. This quotation is from the Commission's own 2008 assessment of the impact of the OMC:

Delivery on the common objectives has been too slow or insufficient ... there is a widespread consensus that the potential of the Social OMC remains largely unexploited, that a number of weaknesses should be corrected and that strategic reinforcement of the method would go some way towards improving delivery on the common objectives. The analysis points to a lack of political commitment and visibility and a need for better horizontal policy coordination and mainstreaming of social protection and social inclusion concerns in all relevant policy areas. (SEC(2008)2170: 2)

That kind of review obscures a larger point. The OMC, like many political institutions, is not a single-purpose instrument (Zeitlin 2005), and it can do many things that gain supporters (Greer \& Vanhercke 2010). Some of its uses are clear. It is an opportunity for the relevant health ministry officials to learn from each other without the costs of organizing separate conferences. It might help socialize health ministry officials into a more "European" way of working. It is an agenda-setting mechanism (one of a great many) in that it draws attention to member states' performance on specific indicators. It justifies applying for EU funds (European Social Fund) to remedy deficiencies. It probably strengthens some campaigns that were gaining attention anyway, such as Europewide interest in health inequalities. It might strengthen the EU's social policy thinking and legitimate social democratic concerns in a political system with a strong neoliberal 
bias and tight fiscal policies. Each of these uses could, potentially, contribute to a supporting coalition among health ministries and perhaps line health officials concerned with health outcomes who find that the OMC is useful as a normative reference or as a guide. So far, it is not at all clear that such a development is taking place in health; rather, member state health ministry officials spoke of the OMC as a bureaucratic burden (interviews in UK and Germany, October 2009; France, November 2009).

\subsection{Health sector initiatives in health care services}

A second kind of experimentalist EU governance is more specific, better defined, connected with existing professional groups or interests, and found in relatively marginal areas that lack the high costs and high politics of health care services. The same DG Sanco official who was unimpressed with the OMC argued for targeted programs such as cooperation on rare diseases. He quoted Everett Rogers' analysis of the diffusion of innovations, which argues that innovations transfer when possible adopters view them as relatively better than the status quo, compatible with values and other practices, of manageable complexity, trialable so that they can be abandoned if they do not work, and have observable results (October 2009) (Rogers 2003).

His nomination for an effective health program, and a good example of the logic, was the rare diseases action that was just starting. Rare diseases in the EU definition affect a maximum of five per 10,000 people; most countries have only a handful of sufferers of most rare diseases, and so the case for EU action is not hard to make. This program began with a 1999 decision to set up a Europe-wide network as part of the overall EU public health framework (Decision 1295/1999/EC). The network set to developing potential EU actions as well as a newsletter, Internet portal, and large conferences.

The potential supportive coalition for rare diseases policy is visible. Pharmaceutical interests, which are very powerful in the EU and often shape its health agenda (Carboni 2009), support it. Patient and disease focused groups, many of which work very closely with pharmaceutical firms, can be supportive. Doctors and researchers in rare diseases, and their sponsors in health systems, might be supportive. It is not hard to see why parts of the Commission might see an opportunity to provide an EU service that would have a supporting coalition, and the rare diseases issue has the added benefits of sympathetic sufferers and economies of scale. The opposition mostly came from big member states such as Germany that felt they could run good networks internally, without Commission help. Once it was agreed that the networks could exist within a single member state (e.g. Germany), the Council could in June 2009 endorse networks and a coordinating committee (Recommendation 2009/C 151/02) and the Commission made its implementing decision in November 2009 (C2009(9181)).

This activity, a nice example of Commission entrepreneurialism and EU networking in its own right, sparked activities far in advance of the legal requirements of 2009. Activists interested in particular diseases started to connect through the EU network, and member state health ministries either began to collect information about rare disease incidence and treatment or delegated its collection to others such as medical societies. The work was not necessarily hard, but it created a large amount of information and new networks that had not been present in many countries (e.g. for many diseases there was no Austrian guide to treatment or resources, leaving doctors to find diagnostic and treatment initiatives by word of mouth; the Austrian Medical Society delegated members to coordinate and develop the information in late 2008; interview, Austrian Medical 
Society, October 2009). The EU activity acted as a spur to collect information, and now that there is a larger and more sophisticated EU policy machine it might impel member states to use the new, comparable information about resources to improve or coordinate their resources. While there is no EU requirement beyond participation in the network (the legislative instrument, a Recommendation, is very weak), there seems to be an element of competition between member states to provide better treatment. Professional and national pride is a major driver of participation in such networks (Briatte 2010).

The new rare diseases network is one of a number of cases of very specific EU initiatives. There are other cases in which networks have developed to pursue goals. They include blood safety, where EU law obliged member states to create responsible authorities that relied heavily on and strengthened pre-existing networks (Faber 2004; Farrell 2005), cancer research and networking (Trubek et al. 2008), organ donation, communicable disease control (Journal of Health Politics, Policy and Law 2012 36(1)), obesity policy (Jarman 2011), and HIV/AIDS data (Steffen forthcoming). There are also examples outside health in areas such as utility, financial, and telecommunications regulation. In each case, the EU has provided resources and legitimacy for activists who wish to exchange information and increase their ability to pressure their member states. The appeal is to small groups, such as rare diseases or blood specialists - latent networks that can be organized to pool resources, compete, and point to each other's EU-validated work to pressure their member state governments.

In principle, this kind of more specific sectoral initiative can surmount the three obvious problems of the OMC in health: its broad system-level focus, the tendency for OMC work to concentrate in health ministries' international rather than line divisions, and the ease with which comparative health indicators can always be discredited. By drawing on smaller networks with clearer preferences, more specific data concerns, greater lobby support, and professional engagement, it can create coordination and rulemaking where there were only informal shared ideas. But success at the task that interests them, be it rare diseases treatment, cancer research, or blood safety, does not mean that such networks will influence the development of the overall EU policy framework. Their meliorism could coexist with many different EU policies. Nor is the judgment of success definitive: even in cancer and communicable diseases, where the networks have long existed and led to the creation of a well-established cancer research network and an EU communicable disease agency, respectively, the actual effects are difficult to determine.

\section{Conclusion: Appearances and the unexpected}

Constitutional asymmetry is an important part of the EU policy story, but it is not the only part. Health care services policy in the EU has been, so far, driven by supranational political institutions. This means preliminary reference decisions by the ECJ followed by diverse Commission initiatives. There has been little visible demand for the policy, and efforts to legislate the policy have been rebuffed so far, but that has been no impediment to the creation of EU powers, application of the four freedoms, and obligatory changes to member state laws. It is no wonder that such a system has been gradually redefining law and politics across Europe (Kelemen 2010).

But there is a problem with exercising power from above. Policymaking with little or no supporting coalition is a good (literally, textbook Weberian) demonstration of power 
but it is not a route to effective implementation. Implementation of judicial decisions, let alone their conversion into a set of policies and principles with wide application, depends on bureaucrats and individuals who change what they are doing - who comply with decisions or who litigate against the non-compliant. Compliance is so far highly variable, and consequential changes in patient or market behavior have not been clear in the few studies done so far. Even with the support and engagement of some member state courts, there are limits to what the ECJ, or any top court, can do to change policy if the supporting coalitions are weak.

Against that backdrop, of the unexpected weakness of apparently strong policy, we might also notice the unexpected strength of apparently weak policy. If the common denominator of effective policies is a supporting coalition, then experimentalist governance mechanisms with supporting coalitions can have more desired effects than court cases or even laws that lack such supporting coalitions.

Reading the history of EU health care services policy to date, the story is of constitutional asymmetry, with the EU institutions and a very few allies in the member states able to create competencies where none were desired and to apply the law of the four freedoms without much attention to competing priorities or policy complexity. It means that there has been abundant reason to view the EU as a basically liberalizing force that cannot muster sufficient positive integration to preserve solidarity and financial stability in health. But the ECJ's power, shown in its health care jurisprudence, is vulnerable to implementation failure, and the judges might lose interest if they run short of new cases or opportunities to make workable decisions. Law alone, without a supporting coalition, is not as effective as it might seem on paper, while network-based experimentalist governance need not be as ineffective as it might look.

\section{Acknowledgments}

I would like to thank Rita Baeten, Jennifer Fredette, Carol Heimer, Holly Jarman, Dorte Martinsen, Margitta Maetzke, Rosemary Taylor, Louise Trubek, Jonathan Zeitlin, and two anonymous referees for their comments. Earlier versions of this article have been presented at the Conference of Europeanists, Montreal, April 2010 and at "Smart Regulation: Can New Types of Governance Improve Health?", University of Wisconsin-Madison, 9 October 2009. This research was primarily supported by the National Science Foundation program in Law and Social Sciences (SES-071963). Interviews before 2008 were supported by the Nuffield Trust.

\section{Notes}

1 All the relevant documents are available on the PRELEX page for the Directive, http:// ec.europa.eu/prelex/detail_dossier_real.cfm?CL=en\&DosId=197193, [Last accessed 14 March 2011].

2 Case C-372/04 Watts; compare the opinion of Advocate General Geelhoed, delivered on 15 December 2005.

3 Case C-157/99 Geraets-Smits and Peerbooms. The reference to the need for broader criteria than the member state is in paragraphs $94-96$.

4 Council declaration 2006/C146/01.

5 See 2008/0142 (COD), Council note of 26 November 2009, paragraphs 21-24, for states' concern about this point. 
6 As has taken place with other services: pharmacy C-22/2001 Doc Morris (2003), and ambulance services C-475/99 Ambulanz Gloeckner (2001), where the underlying legal principle could have substantially deregulated and/or created cross-border arbitrage but the decision largely left regulation intact.

\section{Cases cited}

\section{Court of Justice}

C-120/95 (1998) Nicolas Decker v Caisse de Maladie des Employés Privé.

C-157/99 (2001) B.S.M. Geraets-Smits and Stichting Ziekenfonds VGZ and between H.T.M. Peerbooms and Stichting CZ Groep Zorgverzekeringen.

C-158/96 (1998) Raymond Kohll v Union des Caisses de Maladie.

C-173/09 (2010) Georgi Ivanov Elchinov $v$ Natsionalna zdravnoosiguritelna kasa.

C-322/01 (2003) Deutscher Apothekerverband eV v DocMorris NV and Jacques Waterval.

C-372/04 (2005) Yvonne Watts $v$ Bedford Primary Care Trust and Secretary of State for Health.

C-475/99 (2001) Firma Ambulanz Glöckner v Landkreis Südwestpfalz.

\section{Court of First Instance}

C-199/58 (2007) Asklepios Kliniken GmbH v Commission of the European Communities.

C-79/48 (2008) BUPA and others v. Commission.

\section{References}

Alter KJ (2001) Establishing the Supremacy of European Law. Oxford University Press, Oxford.

Alter KJ, Vargas J (2000) Explaining Variation in the Use of European Litigation Strategies: European Community Law and British Gender Equality Policy. Comparative Political Studies 33, 452-482.

Anderson P (2009) The New Old World. Verso, London.

Baeten R, Vanhercke B, Coucheir M (2010) The Europeanisation of National Health Care Systems: Creative Adaptation in the Shadow of Patient Mobility Case Law. Observatoire Social Européenne, Brussels. [Last accessed 14 March 2011.] Available from URL: http://www.ose.be.

Börzel TA (2006) Participation through Law Enforcement: The Case of the European Union. Comparative Political Studies 39, 128-152.

Briatte F (2010) The Europeanization of Health System Performance: The EUROCARE Study and Cancer Control in England. CERAPS, Lille.

Busse R, Wismar M, Berman PC (eds) (2002) The European Union and Health Services: The Impact of the Single European Market on Member States. IOS/European Health Management Association, Amsterdam.

Canon BC, Johnson CA (1999) Judicial Policies: Implementation and Impact. CQ, Washington, DC.

Carboni N (2009) Advocacy Groups in the Multilevel System of the European Union: A Case Study in Health Policy-making. Observatoire Social Européenne, Brussels. [Last accessed 14 March 2011.] Available from URL: http://www.ose.be.

Carrera P, Lunt N (2010) A European Perspective on Medical Tourism: The Need for a Knowledge Base. International Journal of Health Services 40, 469-484.

Cichowski RA (2007) The European Court and Civil Society: Litigation, Mobilization and Governance. Cambridge University Press, Cambridge.

Conant L (2002) Justice Contained: Law and Politics in the European Union. Cornell University Press, Ithaca, NY.

Cram L (2009) From "Integration by Stealth" to "Good Governance" in EU Social Policy. In: Tömmel I, Verdun A (eds) Innovative Governance in the European Union: The Politics of Multilevel Policymaking, pp. 87-101. Lynn Rienner, Boulder, CO. 
Crespy A (2010) When Bolkestein is Trapped by the French Anti-liberal Discourse: A Discursive Institutionalist Account of the French Position on the EU Services Directive. Journal of European Public Policy 17, 1253-1270.

Epp CR (2008) Law as an Instrument of Social Reform. In: Whittington KE, Kelemen RD, Caldeira GA (eds) The Oxford Handbook of Law and Politics, pp. 595-613. Oxford University Press, Oxford.

European Commission (2001). European Governance: A White Paper. COM(2001)428. European Commission, Brussels.

European Commission (2008a) Proposal for a Directive of the European Parliament and of the Council on the application of patients' rights in cross-border healthcare. $\mathrm{COM}(2008) 414$. European Commission, Brussels.

European Commission (2008b). Commission staff working document - "A renewed commitment to social Europe: reinforcing the open method of coordination for social protection and social inclusion" - Impact assessment. COM(2008) 418 final; SEC(2008) 2170. European Commission, Brussels.

Faber J-C (2004) The European Blood Directive: A New Era of Blood Regulation Has Begun. Transfusion Medicine 14, 257-273.

Farrell A-M (2005) The Emergence of EU Governance in Public Health: The Case of Blood Policy and Regulation. In: Steffen M (ed.) Health Governance in Europe, pp. 134-151. Routledge, London.

Ferrera M (2005) The Boundaries of Welfare: European Integration and the New Spatial Politics of Social Protection. Oxford University Press, Oxford.

Glinos IA, Baeten R, Helble M, Maarse H (2010a) A Typology of Cross-border Patient Mobility. Health \& Place 16, 1145-1155.

Glinos IA, Baeten R, Maarse H (2010b) Purchasing Health Services Abroad: Practices of Cross-border Contracting and Patient Mobility in Six European Countries. Health Policy 95, 103-112.

Graziano P, Vink MP (eds) (2007) Europeanization: New Research Agendas. Palgrave Macmillan, Basingstoke.

Greer SL (2006) Uninvited Europeanization: Neofunctionalism and the EU in Health Policy. Journal of European Public Policy 13, 134-152.

Greer SL (2008) Choosing Paths in European Union Health Policy: A Political Analysis of a Critical Juncture. Journal of European Social Policy 18, 219-231.

Greer SL (2009) The Politics of European Union Health Policies. Open University Press, Buckingham.

Greer SL (2010) Standing Up for Health? Health Departments in EU Health Policy Formulation. Social Policy and Administration 44, 208-224.

Greer SL, Rauscher S (2011a) When Does Market-marking Make Markets? EU Health Services Policy at Work in the United Kingdom and Germany. Journal of Common Market Studies, DOI: 10.1111/j.1468-5965.2010.02157.x.

Greer SL, Rauscher S (2011b) Destabilization Rights and Restabilization Politics: Policy and Political Reactions to European Union Health Care Services Law. Journal of European Public Policy 18, 220-240.

Greer SL, Vanhercke B (2010) The Hard Politics of Soft Law. In: Mossialos E, Permanand G, Baeten R, Hervey T (eds) Health Systems Governance in Europe: The Role of EU Law and Policy, pp. 186-230. Cambridge University Press, Cambridge.

van de Gronden J (2009) The Services Directive and Services of General (Economic) Interest. In: Krajewski M, Neergaard U, van de Gronden J (eds) The Changing Legal Framework for Services of General Interest in Europe: Between Competition and Solidarity, pp. 233-254. TMC Asser, The Hague.

Hatzopoulos V (2007) Why the Open Method of Coordination Is Bad for You: A Letter to the EU. European Law Journal 13, 309-342. 
Hatzopoulos V (2010) Public Procurement and State Aid in National Health Care Systems. In: Mossialos E, Permanand G, Baeten R, Hervey T (eds) Health Systems Governance in Europe: The Role of EU Law and Policy, pp. 379-418. Cambridge University Press, Cambridge.

Héritier A (2001) Differential Europe: The European Union Impact on National Policymaking. In: Héritier A, Klerwer D, Knill C, Lehmkuhl D, Teutsch M, Douillet A-C (eds) Dfferential Europe: The European Union Impact on National Policymaking, pp. 1-22. Rowman and Littlefield, Lanham, MD.

Hervey T, Vanhercke B (2010) Health Care and the EU: The Law and Policy Patchwork. In: Mossialos E, Permanand G, Baeten R, Hervey T (eds) Health Systems Governance in Europe: The Role of EU Law and Policy, pp. 84-133. Cambridge University Press, Cambridge.

Jarman H (Forthcoming) Collaboration and Consultation: Functional Representation in EU Stakeholder Dialogues. Journal of European Integration.

Jarman H, Greer SL (2010) Crossborder Trade in Health Services: Lessons from the European Laboratory. Health Policy 94, 158-163.

Jarman H, Kowalski K, Amodeo J (2010) Medical Tourism: The Implications of European Union Debates for Healthcare Quality and Access in the United States. Rockefeller College of Public Affairs, Albany, NY.

Kelemen RD (2010) Eurolegalism. Harvard University Press, Cambridge, MA.

Kleinman M (2002) A European Welfare State? European Union Social Policy in Context. Palgrave Macmillan, Basingstoke.

Lamping W, Steffen M (2009) European Union and Health Policy: The "Chaordic" Dynamics of Integration. Social Science Quarterly 90, 1361-1379.

Laugesen MJ, Vargas-Bustamente A (2010) A Patient Mobility Framework That Travels: European and United States-Mexican Comparisons. Health Policy 97, 225-231.

Leibfried S, Pierson PA (eds) (1995) European Social Policy: Between Fragmentation and Integration. Brookings Institution, Washington, DC.

Martinsen DS (2005) Towards an Internal Health Market with the European Court. West European Politics 28, 1035-1056.

Martinsen DS, Blomqvist P (2009) The European Union: Single Market Pressures. In: Magnussen J, Vrangbaek K, Saltman RB (eds) Nordic Health Care Systems: Recent Reforms and Current Policy Challenges, pp. 294-315. European Observatory on Health Systems and Policies, Brussels.

McKee M, Mossialos E, Baeten R (2002a) EU Law and the Social Character of Health Care. Peter Lang, Brussels.

McKee M, Mossialos E, Baeten R (2002b) The Impact of EU Law on Health Care Systems. Peter Lang, Brussels.

Martinsen DS, Vrangbaek K (2008) The Europeanization of Health Care Governance: Implementing the Market Imperatives of Europe. Public Administration 86, 169-184.

Moravcsik A (2002) In Defence of the "Democratic Deficit:" Reassessing Legitimacy in the European Union. Journal of Common Market Studies 40, 603-624.

Newdick C (2009) Cross-border Health Care Rights, the European Court of Justice and Social Citizenship: Accidental Death of A Concept? Wisconsin International Law Journal 26, 844-868.

Obermaier AJ (2009) The End of Territoriality? The Impact of ECJ Rulings on British, German and French Social Policy. Ashgate, Aldershot.

Page EC (2005) Joined-up Government and the Civil Service. In: Bogdanor V (ed.) Joined-up Government, pp. 139-155. Oxford University Press/British Academy, Oxford.

de la Porte C, Pochet P, Room G (2002) Social Benchmarking, Policy-making and the Instruments of New Governance. Journal of European Social Policy 11, 291-307.

Rogers E (2003) The Diffusion of Innovation, 5th edn. Free Press, New York, NY.

Rosenberg GN (1991) The Hollow Hope: Can Courts Bring About Social Change? University of Chicago Press, Chicago, IL. 
Rosenmöller M, McKee M, Baeten R (eds) (2006) Patient Mobility in the European Union: Learning From Experience. European Observatory on Health Systems and Policies, Brussels.

Sabel CF, Zeitlin J (2007) Learning from Difference: The New Architecture of Experimentalist Governance in the European Union. European Law Journal 14, 271-327.

Sabel CF, Zeitlin J (eds) (2010) Experimentalist Governance in the European Union: Towards A New Architecture. Oxford University Press, Oxford.

Scharpf FW (2002) The European Social Model: Coping with the Challenges of Diversity. Journal of Common Market Studies 40, 645-670.

Schout A, Jordan A, Twena M (2010) From "Old" to "New" Governance in the EU: Explaining a Diagnostic Deficit. West European Politics 33, 154-170.

Shore C (2007) European Integration in Anthropological Perspective: Studying the "Culture" of the EU Civil Service. In: Rhodes RAW, t'Hart P, Noordegraf M (eds) Observing Government Elites: Up Close and Personal, pp. 180-205. Palgrave Macmillan, Basingstoke.

Smith MP (2005) States of Liberalization: Redefining the Public Sector in Integrated Europe. SUNY, Albany, NY.

Sokol T (Forthcoming) Rindal and Elchinov: An (Impending) Revolution in the EU Law on Patient Mobility? Croatian Yearbook of European Law and Policy.

Steffen M (Forthcoming) The Europeanization of HIV and AIDS Politics. Journal of Health Politics, Policy and Law.

Streeck W, Schmitter PC (1991) From National Corporatism to Transnational Pluralism. Politics and Society 19, 133-165.

Trubek L, Nance M, Hervey T (2008) The Construction of Healthier Europe: Lessons from the Fight against Cancer. Wisconsin International Law Journal 26, 804-844.

Weber M (1946) "Class, Status, Party" In: Gerth HH, Mills CW (eds) From Max Weber: Essays in Sociology, pp 180-195. New York: Oxford University Press.

Wincott D (2003) Implementing the "New Open Method of Coordination" in the Field of Social Inclusion. Public Administration 81, 533-553.

Wismar M, Palm W, Figueras J, Ernst K, van Ginneken E (eds) (2010) Cross-border Healthcare in the EU: Mapping and Analysing Practices and Policies. European Observatory on Health Systems and Policies, Brussels.

Zeitlin J (2005) Introduction: The Open Method of Co-ordination in Question. In: Zeitlin J, Pochet P (eds) The Open Method of Co-ordination in Action: The European Employment and Social Inclusion Strategies, pp. 19-35. Peter Lang, Brussels. 